\title{
タイヤにおけるシリカ配合技術の最近の技術課題 Recent Advance in Silica Tire Technology
}

日 座 操
Misao HIZA

\section{はじめに}

先の ITEC2000 (International Tire Exhibition and Conference 2000, AKRON) において, Michelinの 「ラジアルタイヤ」が 20 世紀最大の技術革新に選ばれた1。 ラジアル化は夕イヤ性能を大幅に改善した歴史的な革新 であるが，それに匹敵する夕イヤの技術革新が最近急速 に進行している。それが「シリカタイヤ」である。シリ カタイヤとは, 従来のカーボンブラック補強の代わりに シリカを補強材として使用したタイヤである。このシリ カタイヤの技術とはどういうもので, その現状と今後に ついての文献等を整理する。特に, シリカタイヤ実用化 の最大のポイントは, シリカとポリマーの補強であり接 着である。それを担うシランカップリング剤の役割とそ の反応に着目する。

\section{1. シリカのタイヤへの応用の歴史}

1970 年代に Metzler がブルータイヤとして出したの が最初のシリカタイヤと言われている。これは文字通り 青い夕イヤであったが, 摩耗性が悪く実用化されなかっ た。このタイヤはシリカを添加しただけであったためゴ ムとシリカ界面が補強されず脆い材料であった。一方, 大型タイヤのチップカット防止のためにシリカを $5 \%$ 程 度以下添加することは現在も実施されている。この場合 は，カップリング剂を使用せず，シリカはモデュラスを 下げ，伸びを出す役割で使用されている。

1990 年代になり, Michelinがグリーンタイヤを発表

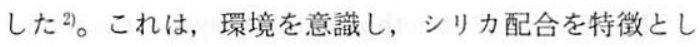

\footnotetext{
*横浜ゴム(胡平塚製造所

タイヤ材料設計部 2 グルーブ 主幹

神奈川県平塚市追分 2-1 于 254-8601

Tire Material Development Department

The Yokohama Rubber Co., Ltd.

2-1 Oiwake, Hiratsuka-shi, Kanagawa 254-8601 Japan
}

た低燃費性に優れた性能のタイヤであった。地球環境保 護という意識の高まりとともに，このグリーンタイヤと いう考えが欧州を中心に急速に広まってきている3)。

当初は, シリカは低燃費化のための技術と理解され, 欧州以外では，それ程興味をもたれなかった。ところが， 湿潤路面での性能（WET 性能）や低温性能（例えば氷 上路面での性能）に優れることが次第に明らかになり, 爆発的にシリカタイヤが広まり,興味をむたれるように なってきた。

\section{2. シリカタイヤの現状}

スミサースレポードにによると現在欧州のシリカの利 用は平均で $20 \%$, 特に乗用車用途では $32 \% に$ 達してい る。欧州の $\mathrm{OE}$ 向けタイヤの場合, シリカ入りは必要条 件になりつつある。一方, 冬タイヤではシリカタイヤの 比率が $50 \%$ に達している。欧州の場合, ガソリンが高 く，燃費を良くするタイヤには大きなインセンティブが あり, そのため急速にシリカタイヤが增えたと言われて いる。

米国では, ガソリンが安く、それほどグリーンタイヤ への訴求性が高くない。むしろ, 米国市場では WET 性 能を含む安全性の面から拡大すると予想されている。日

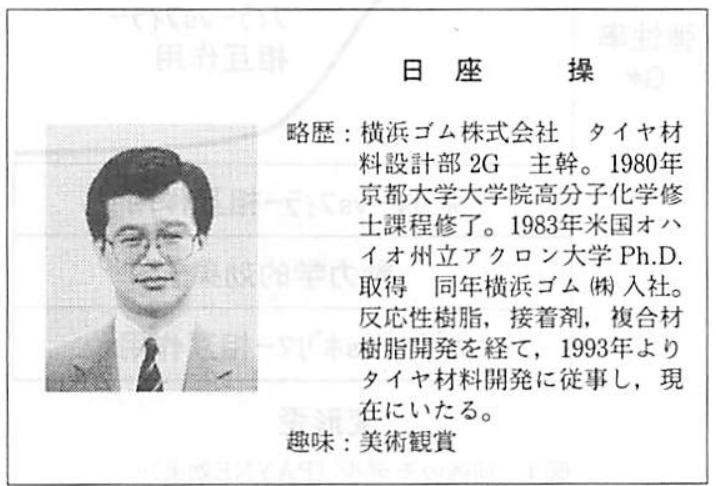


本ではガソリンは欧州同様高いが, 元々タイヤの低燃費 化技術は進んでいたために，シリカタイヤの必要性が低 く，そのため米国同様シリカタイヤの普及は遅れていた。 しかし, シリカタイヤの WET 性能と冬性能がカーボン よりあ明らかに優れることが認識され, 最近急速にシリ カの利用技術が進展し始めている。

\section{3. フィラーーポリマー相互作用}

初期のタイヤは酸化亜鉛を配合した白い夕イヤであっ たが, 1904 年 Mote がゴムにカーボンブラックを加え て補強することを発見して以来, タイヤは黒いものになっ た4)。カーボンブラックによる補強は, 引張強度, 引裂 強度, 耐摩耗性を大幅に向上させるむのである。この補 強効果は, 単純な物理的な補強効果だけでは説明できず, ポリマーvsポリマー, ポリマーvsフィラー, フィラー vs フィラーの相互作用が複合的に働き, 大きな補強効 果を出している5)。

図1に弾性率とせん断变形ひずみのプロットを示し た6)。ポリマーの架橋による効果がポリマーvs ポリマー 相互作用であり, フィラーの物理的補強が動力学的効果 を示すが, いずれも变形ひずみには影響を受けない。ま た, フィラー自身の形状因子 (一次構造や二次構造など) やフィラーとポリマー相互作用効果がポリマーvsフィ ラー効果になる。これらも変形ひずみに影響を受けない。 このポリマーvsフィラーの相互作用は, 後述するが, シリカとカーボンブラックの違いが大きく反映している。 一方, Payne 効果〕しして良く知られるのがフィラー vs フィラー相互作用で, 変形ひずみが大きくなると, フィラー同士の相互作用（van der Waals 力など）は壊 れ, 弾性率が低下する。このフィラー相互作用は, カー ボンブラックの場合大きな凝集体構造を取り, より強く 出, カーボンブラック系の高物性に起因している。図 1

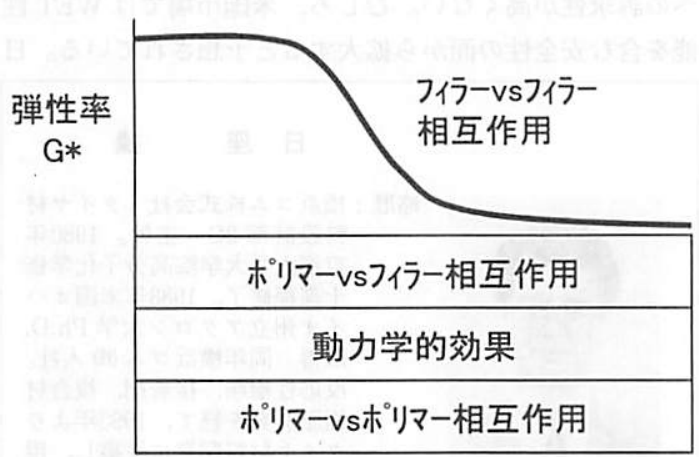

変形歪
図1 補強のモデル (PAYNE効果) ${ }^{7)}$

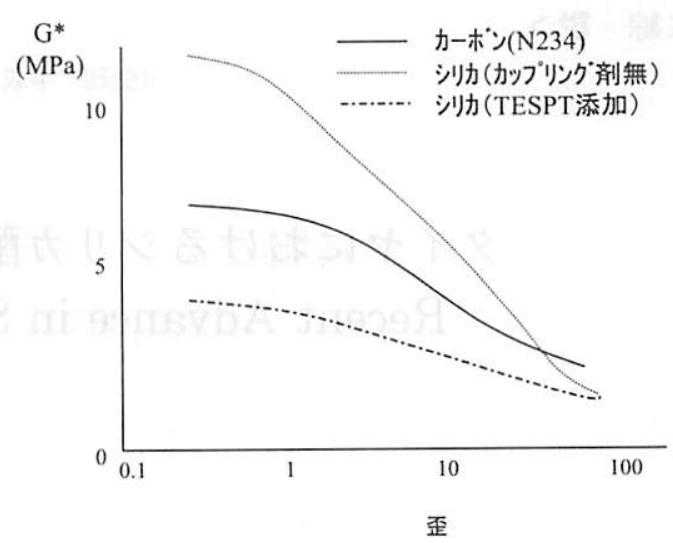

図 2 せん断弾性率の歪依存性 ${ }^{81}$

に示すように, 高ひずみでは, この凝集体構造が壊れや すく, 弾性率の低下につながる (Payne 効果)。

一方シリカの場合, シリカ表面のシラノール基を通し てシリカ同士が水素結合を形成する。シリカはこの水素 結合により，より強固な凝集体を形成し，図 2 にあるよ うに, ひずみに対する依存性が大きい。しかし，カップ リング敦などを使用すると, シリカ表面のシラノール基 の水素結合が抑制され，凝集体同士の相互作用を下げる ことが出来る。それにより, Payne 効果は小さく, む しろポリマーvs シリカの相互.作用か強〈なる8)。また, シリカ同士の相互作用が小さくなることにより, シリカ のポリマーへの分散が容易になり, 低燃费性や耐摩耗性 向上につながる。

\section{4. シリカvs ポリマーの相互作用}

シリカ表面は水を含み親水性で, 親油性のポリマーと の相互作用は弱い。そこで, シリカ表面を改質するため に, シランカップリング剂を使用する。シリカ表面を改 質すれば, シリカ凝集体同士の相互作用が弱まり, シリ カが分散しやすくなる。これが従来のシリカの欠点（耐 破壊性や耐摩耗性）を大幅に改善することになり，最近 のシリカ拡大に大きく貢献している。図 2 に示すように カップリング剂を添加することにより弾性率が大幅に低 下し, 劇的にフィラーvsフィラー相互作用を変化させ る。

シランカップリング剤TESPT（式 1) はシリカタイ TESPT: (Bis(3-triethoxysilylpropyl)tetrasufane ヤで現在一番良く使用されているシランカップリング剤

式 1 TESPT

(Bis(3-triethoxysilylpropyl)tetrasufane

(EtO) $)_{3} \mathrm{SiCH}_{2} \mathrm{CH}_{2} \mathrm{CH}_{2} \mathrm{SSSSCH}_{2} \mathrm{CH}_{2} \mathrm{CH}_{2} \mathrm{Si}(\mathrm{OEt})_{3}$ 
である。TESPT は, シリカ表面のシラノール基と縮合 反応するエトキシ基とポリマーのジエン構造と架橋反応 するテトラスルフィドとからなる。

TESPT のエトキシ基は, 混合あるいは加硫中に加水 分解反応して, シラノール化し, シリカ表面のシラノー ル基と縮合反応する。シリル化との縮合反応は，ほぼ同 時に起こると報告されている。そして, TESPT 中のテ トラスルフィドは $160^{\circ} \mathrm{C}$ 以上熱が加わると容易に開裂 してラジカルを発生し, ジェンゴムと架橋反応を引き起 こす。この反応により，シリカとポリマーはシランカッ プリング剤を通して化学結合で結び付けられ, シリカ配 合の欠点であった耐摩耗性の改良に大きく寄与した。ま た, 化学結合の形成により発熱も抑制され, 転がり抵抗 も低下した。シランカップリング剂とポリマー, シリカ の反応を図 3 に示した。
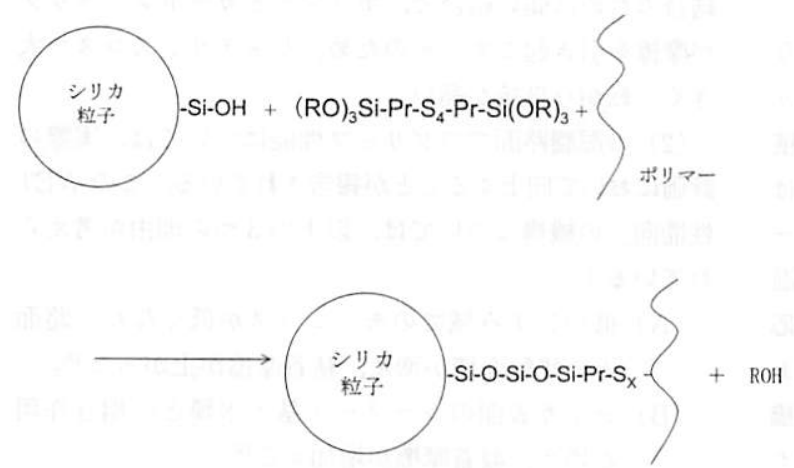

図 3 シランカップリング剤とポリマー, シリカの反応

\section{5. シランカップリング剂の役割}

シランカップリング阂の反応について, DEGUSSA

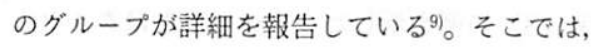

1） TESPT の濃度は低い方がアルコキシシランの加水 分解反応が速い。TESPT 濃度の適值はシリカに対 して $8 \%$ 前後。

2）シリカとシランの反応は, 酸性（ $\mathrm{pH} 4.3 ）$ あるいは アルカリ性（pH8.1）環境の方が速くなり，またシ リカの含水量が多いほど反応が速い:

反応速度 : $2.6 \% \mathrm{H}_{2} \mathrm{O}<5.5 \% \mathrm{H}_{2} \mathrm{O}<9.0 \% \mathrm{H}_{2} \mathrm{O}$ )

3）第一段階反応（加水分解ーシリカ表面との反応）上 第二段階反応（シラン内部の縮合）の活性化エネル ギーを比較すると

第一段階 : $47 \mathrm{~kJ} / \mathrm{mol}$

第二段階 : $28 \mathrm{~kJ} / \mathrm{mol}$

また，酸性，アルカリ性下ではいずれの反応も速く なるが, 水が多いと, 第一段階は影㸷されないが,第 二段階は速くなる。
またCoranらは，シリカ中の水がカップリング剤の 反応を促進することを報告している ${ }^{10)}$ 。以上のように, シリカとシランカップリング斉の反応は詳細に解析され, 機構解明がなされている。

奏用面では, シランカップリング剂が高価なため, シ リカ含有量が增えると原料コストが大幅にアップする。 それを避けるために, 必要最小限のシランカップリング 剂を使用するための研究が盛んに行われている。例えば, シリカとシランカップリング剂の反応を促進する触媒を 使う ${ }^{11)}$, アルカリ性水溶液を添加し, 加硫促進する ${ }^{12) な ~}$ どの特許が出ている。一方, シリカ表面のシラノール基 の反応性を高めることにより, シランの反応を促進し, 高価なシランカップリング剂の必要量を少なくするとい う報告すある ${ }^{13)}$ 。ポリマーの面から反応を促進するため に種々官能基の導入が試みられているが, 両末端にアル コキシシラン基を導入し, シランカップリング剂不 要なポリマーが提案されている ${ }^{14}$ 。

\section{6. シランカップリング剂}

シリカタイヤ拡大の障害の一つはコストが高いこ とである。シリカはカーボンブラックよりも高いが, シランカップリング阂（TESPT）は更に高価な原 料である。現在, 複数のメーカーが TESPT 製造 しているが, 今後も供給メーカーが拡大すると予想 される。

現在実用化されている TESPT は実際には複数の スルフィド混合物である。例えば Degussa の Si69 の場合には, S 数は表 1 のような分布をむつ。対比に ジスルフィド結合を主成分にする Si75 のデータを示す。 Si69 は S3-S6 にかけて幅広い分布である。一方, Si75 はS2 を77\%含む。また, 表 2 には, 各種硫黄結合の

表 1 Si69 と Si75 の構造比較

\begin{tabular}{c|c|c|c|c}
\hline $\mathrm{n}$ & 2 & 3 & 4 & $\geqq 5$ \\
\hline $\mathrm{Si} 69$ & 18 & 29 & 25 & 28 \\
\hline $\mathrm{Si} 75$ & 77 & 15 & \multicolumn{2}{|c}{$\geqq 8$} \\
\hline
\end{tabular}

数字は\%を示す

表 2 結合エネルギー

\begin{tabular}{cr}
\hline 結合 & 結合エネルギー \\
\hline$-\mathrm{CS}_{\mathrm{X}} \mathrm{C}-$ & $<268 \mathrm{~kJ} / \mathrm{mol}$ \\
$-\mathrm{CSSC}-$ & $268 \mathrm{~kJ} / \mathrm{mol}$ \\
$-\mathrm{CSC}-$ & $285 \mathrm{~kJ} / \mathrm{mol}$ \\
$-\mathrm{C}-\mathrm{C}-$ & $351 \mathrm{~kJ} / \mathrm{mol}$ \\
\hline
\end{tabular}


結合エネルギーを示した。ポリスルフィド結合は結合エ ネルギーが低くなるので, 熱安定性が悪い。一方ジスル フィド結合は熱安定性に優れるが，スルフィド結合の分 解が遅い。夹用的には, 混合中にスルフィド結合の解離 が起きない条件で, アルコキシシランとシリカの反応を 促進させる混合条件が選択され, 加硫工程でスルフィド 結合の分解による架橋反応を引き起こす。

一方, ジスルフィド構造は熱安定に優れるために, 大 量生産時に混合での温度制御が容易になるメリットがあ るが15)，ポリスルフィドよりも高価なために実用化が遅 れている。

TESPT に代わるカップリング剤の研究は多いが, TESPT 全量を完全に置換するものはなく，部分的に TESPT を置換できるものが報告されている16)。

\section{7. 混合機中での反応}

シリカの混合は, シランカップリング剤の反応を伴う ために混合温度の制御範讲が狭く, 従来のカーボンブラッ クの混合とは大幅に異なる。実際の混合は例えば容積 $330 \mathrm{dm}^{3}$ を使用する場合 ${ }^{17)}$, 混合機内の温度ばらつきは $20^{\circ} \mathrm{C}$ るいはそれ以上になる。このばらつきはローター の形状や加工条件に依存する。そして, 混合機の平均温 度と最高温度の安全域を使う必要がある。シリル化反応 のためには，最適で $145 \sim 155^{\circ} \mathrm{C}$ の温度制御が必要であ り， $160^{\circ} \mathrm{C}$ 以上ではテトラスルフィドの分解による架橋 反応が始まる。 $145^{\circ} \mathrm{C}$ 以下ではカップリング剂がシリカ と反応しないために，物性が上がらない。

\section{表 3 シリカ混合の具体例 ${ }^{17}$ )}

\begin{tabular}{|c|c|}
\hline 混合量 & $270 \mathrm{~kg} （$ 容積 $330 \mathrm{dm}^{3}$ : 充填率 70\%） \\
\hline シリカ量 & $95 \mathrm{~kg}(80 \mathrm{phr})$ \\
\hline シラン量 & $7.6 \mathrm{~kg}(6.4 \mathrm{phr})$ \\
\hline エタノール量 & $1.3 \mathrm{dm}^{3}\left(150^{\circ} \mathrm{C} て ゙ は ~ 1 \mathrm{~m}^{3}\right.$ のエタノール蒸気量) \\
\hline 水 & $\begin{array}{r}4.8 \mathrm{~kg} \quad(4-6 \text { 重量\% シリカ含有量) } \\
150^{\circ} \mathrm{C} \text { では } 9 \mathrm{~m}^{3} \text { の水蒸気 }\end{array}$ \\
\hline
\end{tabular}

また，混合では反応生成物が発生する。表 3 に代表的 な混合の例を示した ${ }^{17)}$ 。多量のエタノールと水が発生す るために、これらを混合中に除去することが必要になる。 そのために, シリカ混合での必要条件は

1）混合槽内温度の均一化

2）混合槽内温度の制御

3）化学反応の制御

4）反応生成物の除去

などがあり，各社のノウハウとして蓄積されている。シ
リカによる混合設備の摩隇や副生成物による配管の腐食 などの問題もある。

\section{8. シリカの作用機構}

シリカタイヤが最近注目されたのは

(1) 転がり抵抗が低い

（2）湿潤路面でのグリップ性能（WET 性能）が良い

（3）低温性能が良い。

である。（1）はカーボンブラックの場合は，カーボン凝 集体同士の摩擦が大きく，エネルギーをロスし，発熱が 大きく，転がり抵抗が大きくなる。シリカの場合には， シリカ同士の摩擦はシランカップリング剂を併用するこ とにより低く抑えることが出来，低転がり，低発熱にな る。あるいはシリカは化学結合でポリマーと反応するの で強い結合で結びつく。一方, カーボンブラックは物理 結合のために弱い結合で，ポリマーとカーボンブラック が摩擦を引き起こす。そのため。ヒステリシスロスが大 きく, 転がり抵抗が高い。

（2）の湿潤路面でのグリップ性能については，実際の 評価において向上することが報告されている。この WET 性能向上の機構については, 以下の 3 つの理由が考えら れている :

（A）低いひずみ域でのモデュラスが低くなり，路面 之の接触面積が增え, 粘着摩擦が上がった ${ }^{18)}$ 。

（B）シリカ表面のシラノール基と水膜との相互作用 が增え，凝着摩擦が増加する

（C）ヒステリシスロスが增え,ヒステリシス摩擦が上 がった ${ }^{19)}$ 。

特に最近 ABS が標準装備されるようになると, ブレー キの効果も変化してきた。図 4 に代表的な摩擦係数 $(\mu)$ とすべり率 $(\mathrm{S})$ の例を示した。すべり率とはタイヤと

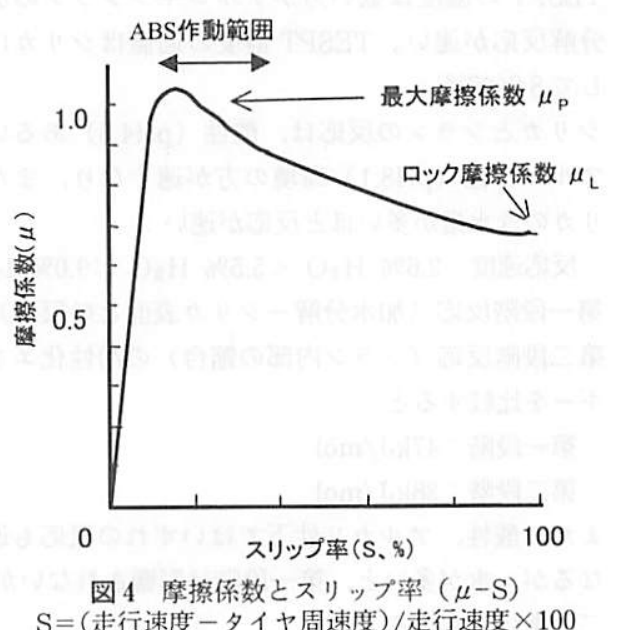


路面のすべりであり, S=0\%はすべりがなく, S=100\% は夕イヤがロックした状態である。従来は, ロック状態 での摩擦であったが, 現在の ABS は低すべり率の範囲 で作動することもあるために，摩擦係数のピーク付近を 活用することが出来, 低すべり率で制動力が働く。低す ベり率の場合, 凝着摩擦が強く作用すると報告されてい る20)。(A) (B) に示すように, シリカの場合は, 凝着摩 擦が大きくなるので, ABS 制御ではシリカが凝着摩擦 をより強くし，WET 性能が向上すると説明できる。

3）の低温性能が良いのは, カーボンブラックの場合 には物理結合を通してカーボンブラックの迴りにゲルを 形成するためにポリマーが拘束される。一方, シリカ の場合にはポリマーとの相互作用は化学結合を形成する ことによるが, ポリマーはカーボンブラックよりも拘束 を受け難いため, ポリマーが自由に動ける。そのために 低温性能が良くなる。

しかしながら, シリカとポリマーの相互作用について は十分に理解されているとは言い難い。より分子論的レ ベルでの議論が必要である。

\section{9. シリカに代わる技術}

シリカをきっかけに新しいフィラーへの取組みが報告 されている。クレーやアルミナはカップリング剂との併 用でシリカと同様の効果が出るが, 比重が重い欠点を持 つ21) ために, 実用化されていない。水酸化アルミニウ ムや炭飘カルシウムはカップリング剂無しでも性能が出 ると報告されている。特に, 水酸化アルミニゥムはシリ 力と類似した性能をむち, WET 性能に優れ, シリ力と 同様にタイヤ性能を向上することができる ${ }^{221}$ 。また，デ ンプンをカップリング風と併用で使う技術もある。有機 物のためにカーボンブラックやシリカに比べ比重が軽い フィラーであり，低燃費に寄与すると報告されている ${ }^{23)}$ 一方, カーボンブラック表面にシリカを付着させたカー ボンブラックとシリカのハィブリッドフィラーが開発さ れた (シリカ結合カーボンTM)。図 5 にその TEM 写真 示したが, シリカがカーボンブラック表面に付着してい る。このフィラーを配合すると, カーボンブラックと同 様に混合加工ができ，コンパウンド性能がシリカライク という材料で, シリカの欠点（加工性が悪い, 電気抵抗 が高い）を改善できる材料である。低㜣費と高いグリッ プを両立するタイヤに使用されている24)。

\section{今後の動向}

シリカタイヤは, 低転がりとWET 性能改善に有利な フィラーであることが判明し, 現在世界中で拡大されよ うとしている。カーボンブラックが使われて 100 年であ

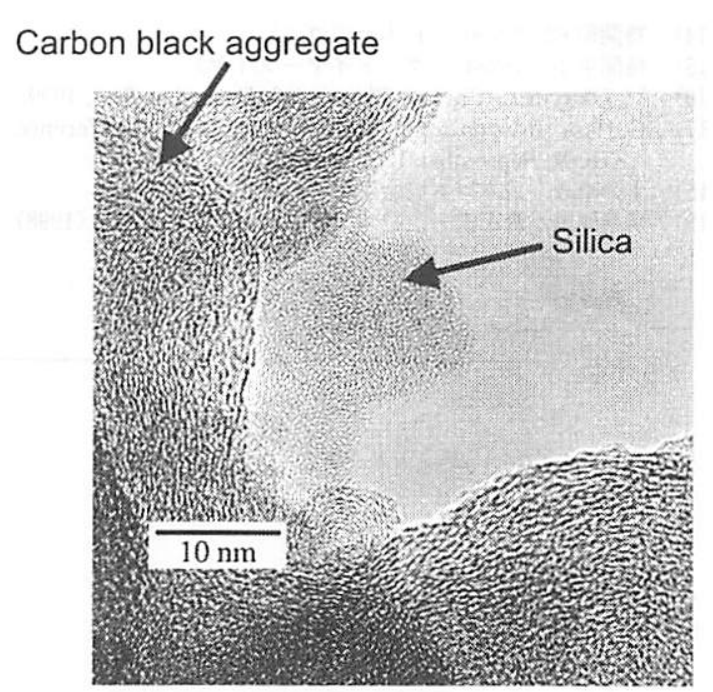

図 5 シリカ結合カーボンTM の TEM 画像

るが, 今後シリカがカーボンブラックを置き換えられる 可能性もある。ただ現状では摩耗レベルがカーボンより も劣るので, 耐摩耗性改良が急がれる。摩耗の改良之は, シリカとポリマーの相互作用の改良を意味し，それには シランカップリング斉を効果的にシリカとポリマーに反 応させれば良い。現在, この相互作用を高めるためにポ リマー, フィラー, カップリング斉の 3 面からのそれぞ れ研究が進んでいる。

以上のように, シリカタイヤの最近の動向を報告した が, シランカップリング剂の活用により, シリカがタイ ヤ性能を大きく変えようとしている。この技術革新は夕 イヤの歴史を変える大きな流れになるだろう。

\section{引用文 献}

1) International Tire Exhibition and Conference, Akron, September 12-14, 2000.

2)例えばUSP 52227425

3) L. White, European Rubber J., 181(12), 26 (1999); ある は T. Harris, Functional Tire Fillers 2001, Florida, Jan. 29-31 (2001)

4) M. Morton, Ed. Rubber Technology $2^{\text {nd }}$ Ed., Van Nostrand Reinhold Co., p. 52 (1973).

5) J. B. Donnet, Rubber Chem. Technol., 71, 323 (1998).

6) S. Wolf and M. J. Wang, Rubber Chem. Technol., 65, 329 (1992)

7) A. R. Payne, Rubber Chem. Technol., 39, 365 (1966)

8) A. McNeish, Functional Tire Fillers 2001, Florida, Jan. 29-31, 2001.

9）U. Gorl and A. Hunsche, 日本ゴム協会誌, 71(9), 549(1998)

10) A. Y. Coran, Functional Tire Fillers 2001, Florida, Jan. $29-31,2001$

11）特開平 11-269313 (ブリヂストン)

12）特開 2000-219779 (住友ゴム工業)

13) P. COCHE, International Tire Exhibition and Conference, Akron, September 12-14, 2000 
14）特開昭 62-227908（日本合成ゴム）

15）特開平 10-182847（グッドイヤータイヤ)

16) M. Okuyama, Carbon Black 1999, December 6-8, 1999.

17) G. Hess, International Tire Exhibition and Conference, AKRON, September 12-14, 2000

18）土井昭政，日本ゴム協会誌，71(9)，588（1998）

19）藤巻達雄, 森田浩一, 日本コム協会誌, 71(9), 562 (1998)
20) J. Eberhardsteiner, W. Fidi and W. Liederer, Kautschk Gummi Kunststoffe 51, Jahrgang, Nr. 11/98

21) USP $5,900,499$ (Michelin).

22) H. Mouri and K. Akutagawa, $153^{\text {rd }}$ Techninal Meeting of the Rubber Div., ACS, Indianapolis, 2000

23) US Patent 5,672,639 (Goodyear Tire)

24）川面哲司，日本ゴム協会誌，73(7)，379（2000） 